This work is licensed under a Creative Commons Attribution 4.0 International License.

Ovaj rad dostupan je za upotrebu pod licencom Creative Commons Imenovanje 4.0 međunarodna.

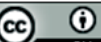

Filip KRAJINA

Filozofski fakultet

Sveučilišta J. J. Strossmayera u Osijeku

Lorenza Jägera 9

HR - 31000 Osijek

fkrajina74@gmail.com

\section{Zdravko PERIĆ}

Filozofski fakultet

Sveučilišta J. J. Strossmayera u Osijeku

Lorenza Jägera 9

HR - 31000 Osijek

zperic@ffos.hr
UDK 821.124.09 Vergilius Maro, P.-1

17

DOI: https://doi.org/10.29162/ANAFORA.v6i1.4

Pregledni članak

Review Article

Primljeno 16. veljače 2019.

Received: 16 February 2019

Prihvaćeno 12. ožujka 2019.

Accepted: 12 March 2019

\title{
MITSKO KAO FILOZOFSKA METODA U VERGILIJEVOJ ENEIDI
}

\section{Sažetak}

U ovom radu razmatramo moguća tumačenja Vergilijeve Eneide iz filozofske perspektive, što uključuje homerski, stoički i epikurejski element, jer usporedba Homerovih epova i Eneide u oblikovanju književnog teksta i filozofičnosti pokazuju podudarnosti. Platonički utjecaj na Vergilija, posredstvom Cicerona i njegova eklektičkog filozofskog pristupa, stoji u učenju o vrlini. Stoga je bitno razdvojiti ideje navedenih filozofskih sustava u Vergilijevu epu te obrazložiti njegov modus izlaganja mitskom filozofskom metodom. Fabulu i uzročno-posljedične veze epa vodi Božja sudbina koja je stoički shvaćena, što znači da je cjelokupna fabularna konstrukcija podređena stvaranju podloge za osnutak Rima kao carstva kojem je Bog namijenio da vlada pravedno i dobro. Uz etičku sastavnicu veže se i ontološka, zato što filozofiju epikurejaca i stoika karakterizira podjela filozofije na etiku, logiku i filozofiju prirode. Enejin model karakterizacije nije stvoren prema stoičkom modelu mudraca, a ni prema epikurejskom, nego glavnu ulogu igra homerski faktor, jer Eneja ipak izražava emocije ljutnje i bijesa kao većina antičkih junaka poput Ahileja i Odiseja, koji, vođeni emotivnom boli i tugom zbog gubitka voljene osobe, postaju osvetnički nasilni. Razlog takvom pripovjednom motivu je idealiziranje emotivnih muškaraca 
u helenskom, a takvim utjecajem onda i u rimskom razdoblju. Dakle, ono što je bilo presudno u oblikovanju glavnog junaka te njegova odnosa prema božanskom je rimska kultura i njezini etičko-ontološki zahtjevi manifestirani religijski. Začetnik mitske filozofske metode strukturirane u epskom pjesništvu je Homer, čiji kasniji utjecaj uspostavlja princip oblikovanja epa. Radi se o metodi iznošenja ideologizirane etike, zbog čega i je kulturalna, a formira se estetiziranjem mitološkog.

Ključne riječi: Ciceron, Eneida, etika, mit, ontologija, Vergilije

\section{Uvod}

Glavni je cilj rada izložiti uvid u filozofski karakter Vergilijeva epa Eneida, za koji slobodno možemo reći da nas od samog početka upućuje na sadržaj stoičke kozmološke etike koja je nužno i ontološka. Osim homerskog, poetičkog, ali i filozofskog utjecaja, u Vergilijevo doba stoičko naučavanje bilo je već aktualno, jer se stoicizam, počevši od Rima, raširio po cijelom sredozemnom svijetu polovinom 2. st. pr. Kr. U 1. st. pr. Kr., kada je Vergilije živio i djelovao, rimskim je stoicizmom vladao Katon Utički (94. - 46.), prvorazredni državnik čije je samoubojstvo postalo »uzor stoičkog mudraca» (usp. Gourinat 2014: 75). Kada govorimo o filozofskom čitanju Vergilija, zasigurno valja naznačiti da su nam u takvom proučavanju presudno važni tekstovi Marka Tulija Cicerona, koji je bio eklektički okrenut, ne samo prema platonizmu i epikurejcima, nego i filozofskim tekstovima Zenona (336. - 264.), Kleanta (331. - 230.) i Hrizipa (280. - 204.), tri filozofa koji pripadaju staroj stoičkoj školi te su zaslužni za cjelokupno stoičko shvaćanje Prirode. ${ }^{1}$ Poznatiji predstavnici srednje stoe jesu Panetije (185. - 110.) s Rodosa i njegov učenik Posejdonije (135. - 51.), »bili su eklektičari i nisu pridonijeli razvoju stoičke filozofije, no njihova je zasluga u

Zeno's contributions to Physics have been unduly depreciated by some authorities but, while it is true that the development of this branch is largely due to Cleanthes, still a fair estimate of the fragments here collected will lead us to the conclusion that the essential groundwork of the Stoic physical teaching was laid by the founder of the school. Zeno started from the proposition that nothing exists but the material, inasmuch as body alone is capable of acting and being acted upon. All body is thus either active or passive and the material world is itself the result produced from the operation of these two principles. The active principle is God, and the passive is matter, rod is more closely denned as the liery aether, which permeates the whole of the universe, even as honey passes through the honeycomb. He is at once the embodiment of reason and of law, and the power which binds in one the various portions of the universe, who, though his essence is constant, appears in different forms in everything that exists. Nature, forethought and fate are thus only different names for the same being; as nature he creates the world, and creates it in entire harmony with the law of fate (usp. Pearson 1891: 10-11). 
tome što su u Rimu svojim predavanjima širili filozofiju stoicizma i pripremili tlo za rimsku filozofiju« (usp. Bošnjak 1957: 17).

Najveći utjecaj i izvor rimske filozofije u 1. st. pr. Kr. leži u učenjima Cicerona i Lukrecija, zato što "njihovi radovi u kombinaciji s ostalima oslikavaju filozofsku atmosferu za Vergilijeva života, što se poklopilo s njegovom mladošću i obrazovanjem, unatoč tome što su Ciceron i Lukrecije živjeli nekoliko desetljeća prije nego je napisana Eneida« (usp. Nash 2017: 1). Zvonimir Milanović ističe da »ukoliko su Ciceronovi metafizički pogledi nastali pod utjecajem platonizma, toliko je, s druge strane, njegov etički svjetonazor proželo učenje nadaleko poznatog stoika Posejdonija« (usp. Milanović 2007: 14). Pod utjecajem Panetija i Posejdonija, stoici su težili približiti svoje učenje platonizmu, vjerojatno po tome i znamo zašto su Ciceronovi pogledi nastali pod utjecajem platonizma. Iz tog razloga, najznačajnija inovacija srednjeg stoicizma bilo je drugačije shvaćanje Boga. Bog - Zeus ili Jupiter, Priroda i Sudbina više nisu jedno biće i njegova bît, nego tri zasebna bića i bîti u međusobnoj povezanosti i poretku. Prvi je Bog, zatim slijedi Priroda, a treća je Sudbina i takva podjela božanskoga omogućila je stoicizmu da se oslobodi panteističkog ontologizma čime je obilježen u ranom razdoblju. Štoviše, stoicizam je, kao i druge filozofije, ušao u otvoreno rivalstvo s kršćanstvom. ${ }^{2}$ I kada je nestao kao aktivan filozofski pokret, »stoicizam je premašio svoju povijesnu kontingentnost i postao sastavnim dijelom opće kulture«, pa će se razjasniti Vergilijev stav prema stoičkoj filozofiji kao takvoj u odnosu na stoicizam kao životni stav, koji je zapravo neodvojiv od uvida u stoicizam kao antički filozofski pokret zato što »stoicizam kao životni stav tvori dio stoicizma okviru filozofskog nauka s izvorom u antici« (usp. Gourinat 2014: 7-8).

Problematizacija koju filozofska tematizacija Eneide nameće leži u pitanju je li Vergilije u svoj ep unosio elemente klasične filozofske tradicije s namjerom ili je svoje epsko pjesništvo koncipirao u okviru tadašnjih rimskih nacionalnih i kulturnih zahtjeva, te koliko su, i u kakvom skladu, pojedini filozofski utjecaji, poput platonizma, epikurejstva i stoicizma, a i mitološki, poput homerske tradicije, zastupljeni u Eneidi. Ostatak rasprave posvetit će se obrazloženju pretpostavke može li se govoriti o mitskom kao filozofskoj metodi epskog pjesništva koje mitološkim nastoji izreći filozofsko u vidu ontološke etike.

Christianity is the the synthetic development of various movements of thought life current at its inception. Repeatedly he who runs may read Christianity is really nothing more than what was already present in the life of the Hellenistic Age. Stoicism especially is chosen as such a preparatory movement (usp. Stob 1935: 217). 


\section{Filozofičnost Vergilijeve Eneide}

Stoici su etiku držali primarnom svrhom filozofije, a fizika i logika bile su supsidijarne toj svrsi, stoga impliciraju ideal mudraca čija je svrha doći do ataraksije slijedeći Boga ili Prirodu koja u mišljenju same sebe konstituira univerzalnu etiku, a njezin je »dio u specifičnom smislu i čovjek s obzirom na koju mu je naloženo da živi« (usp. Todd 2005: 253). Dakle, »zakone kozmosa i njegovo djelovanje čovjek ne može mijenjati, to su činjenice koje čovjek, kada ih upozna, prima kao racionalni smisao samog svijeta « (usp. Bošnjak 1957: 26). Prema tome, "Sudbina je u Eneidi sklona Rimu i širenju njegove moći, tako da su pojedinci koji mu se na bilo koji način opiru, primjerice Didona i Turn, osuđeni na propast « (usp. Beker 1997: 24). U psihološkoj karakterizaciji Eneje postoji odnos ljudskog i božanskog, »on je oličenje i nosilac rimskog pojma vrline i pobožnosti, neprestano svjestan misije što su mu je namijenili bogovi. Eneja se ne suprotstavlja Sudbini, nego je dovoljno mudar da je slijedi« (usp. Vratović 2008: 126-127). Enejin je zadatak ponajprije etički, on je izabran da osnuje Rim koji će vladati dobro i pravedno, kako mu je Sudbina i naložila (usp. Vergilije 2005: 14-15). ${ }^{3}$

\subsection{Ciceronov eklektički utjecaj filozofskih tradicija}

Iz povijesno-filozofske perspektive, prema istraživanju Igora Mikecina:

»Rimsko carstvo je takvo ozbiljenje stoičke istinske zajednice - kosmopolisa, u kojem je Imperij nasilna vladavina nad pokorenima, a ne istinska zajednica u kojoj svojim unutarnjim vlada sâm svjetski um, dakle, helenistička misao manifestirala se u rimskoj kulturi utoliko što se u njemu ljudi izjednačuju kao privatne osobe« (usp. Mikecin 2003: 141-142).

Privatna osoba kao takva zadobiva teret odgovornosti i logično bi bilo zaključiti da u tom trenutku prihvaćanja odgovornosti pojedinac postaje individua, ali prema rimskom shvaćanju takvo tumačenje nije u potpunosti točno zato što Ciceron, kada iznosi što je prikupio o stoičkom i epikurejskom učenju, implicitno zastupa stav o predaji ontološke odgovornosti Sudbini, a jedina odgovornost čovjeka je etička, u prihvaćanju božjeg zakona koji Sudbina provodi, ${ }^{4}$ a u vrlini je, zaključuje Ciceron:

Stihovi 275-296.

4 What is the point then of harping on fate, when everything can be explained by reference to nature and fortune without bringing fate in it? (usp. Cicero MCMXLVIII: 199). Ciceron u De 
»(...) suglasje svih stvari, u njoj je stalnost i postojanost. Kada se vrlina objavi, te pokaže svoju svjetlost $\mathrm{i}$ isto uoči i prepozna u drugome, $\mathrm{k}$ njemu se primiče i prihvaća to što je u drugom: iz toga nastaje plamen ljubavi ili prijateljstva; i ljubav i prijateljstvo znači voljeti« (usp. Ciceron 2007: 158).

Ciceron nam daje do znanja da čovjek istinski jest, u značenju da poštuje božanske zakone, tek onda kada voli. Takvim je stavom Ciceron odgovorio etičkom zahtjevu rimskog svjetonazora o onome »što se tiče čovjeka u njegovoj svakodnevnici, njegov odnos prema zajednici i prema načelima koja upravljaju životom zajednice i pojedinca, jest najvažnije metafizičko pitanje i predstavlja točku u kojoj se svijet prelama u svijetu pojavnosti« (usp. Milanović 2007: 5152). Paralela koju bismo povukli s Ciceronovim definiranjem ljubavi stoji u Aristofanovoj replici u Platonovu Simpoziju, kada pripovijeda da su ljudi nekoć bili spojeni, njihova moć bila je blizu božanske i oholost se javila u njima. Iz straha, bogovi su ih odlučili prepoloviti i otada svaka polovica traži drugu zbog snažnog osjećaja u formi erotske privlačnosti. ${ }^{5}$ Ta ljudska čežnja za svojom drugom polovicom je žudnja za cjelinom, koja će nas međusobno učiniti božanskima, odnosno, što bliže idejama. U ljubavi smo zbog privlačnosti prema idejama i tako postajemo cjeloviti.

Reče i s napetom pažnjom probode ga mačem sred grudi,

Turnu se ukoče udi i tijelo mu počne da studi,

s bolom i ko da se gnuša med sjene odleti mu duša. $(336)^{6}$

Kako vidimo, u posljednjem odlomku Eneide razotkriva se još jedan od elemenata koji bismo mogli povezati sa starogrčkom usmenom književnom tradicijom na što se pozivao još i Pitagora te po uzoru na njega i Platon, a to je mitološki motiv odnosa duše i podzemnog svijeta.

»U razdoblju starog i srednjeg stoicizma gotovo sva važnost pridavana je proučavanju gnoseologije i stvaranju stoičke logike. Tek u razdoblju rimskog stoicizma početkom 1 . st. pr. Kr. važnost se započela pridavati etičkim proble-

Fato navodi argumente za i protiv postojanja Sudbine suprotstavljajući stoičke i epikurejske metafizičke stavove, stoga ne možemo reći da je po tom pitanju jasno opredijeljen. No sagledavajući njegova ostala djela, povijest filozofije zaključila je da ponajviše naginje stoicizmu.

Usp. Platon 1996: 189 c - 193 d, 66-78.

Svi citati preuzeti su iz izdanja: Maron, Publije Vegilije. 2005. Eneida: Prvo pjevanje. U: Eneida. S latinskog preveo Bratoljub Klaić, ur. Zagreb: Globus media, Biblioteka Jutarnjeg lista. Brojevi u zagradama označavaju stranicu u tom izdanju. 
mima, odnosno kako umom, lógosom prevladati patetičnost i afekte« (usp. Jakopec 2018: 96).

U razdoblju rimske filozofije nameće se Ciceronov utjecaj i ako govorimo o stoičkim i platoničkim utjecajima na Vergilijevo epsko stvaralaštvo u okviru rimske kulture, kudikamo najviše pozornosti moramo pridati Ciceronu čiji su filozofski stavovi o vrlini, posredstvom eklektika srednjeg stoicizma Panetija i Posejdonija, nastali pod utjecajem platonizma, ali s fundamentalnim metafizičkim odrednicama stoicizma. Napominjemo da Ciceron nije ni stoik, ni epikurejac, nego je eklektički nastrojen prema filozofiji, što su mu prigovarali njegovi suvremenici, ali Ciceron se upravo ponosio svojim eklekticizmom. Prema tome, moguće je da je i Vergilijev eklekticizam, koji nalazimo u Eneidi, preuzet u skladu s Ciceronovim pristupom.

»Barem što se tiče same povijesti književnosti staroga Rima, razdoblje od 90. do 40. godine prije Krista obično se naziva Ciceronov vijek. Radi se o razdoblju oko prve polovice 2. st. pr. Kr. kada je Rim izašao iz Punskih ratova kao pobjednik, nakon što je razorio Kartagu postavši najveća kopnena i pomorska sila zapadnog svijeta« (usp. Milanović 2007: 5-6).

Prema rimskom praktičnom shvaćanju filozofije, u čemu se najviše razlikuju od starih Grka, filozofija se uklopila u retorici, a Ciceron je, »vođen iskrenim patriotskim idealima, neumorno nastojao primijeniti etička načela usvojena od svojih helenskih učitelja već u ranoj mladosti. Iako u svojim pismima otkriva nostalgiju za filozofijom i razmatranjem teoloških i metafizičkih pitanja (usp. Milanović 2007: 49). U dijaloškoj raspravi o prijateljstvu, Ciceron suprotstavlja patetičnost i afekte spram vrlina, koje su razumske i božanske naravi, pa za tjeskobnost tvrdi da je »u ime prijateljstva često treba primiti na sebe, nije toliko jak razlog da se iz života ukloni prijateljstvo, jednako kao što ne treba udaljiti ni vrline, premda nam donose nemale brige i tegobe (usp. Ciceron 2007: 125). Usprkos tome, Vergilije u svom epu uopće ne pokušava izbjeći otvoreno prikazivanje pogubnih i autodestruktivnih emocija, čime stvara dramski zaplet. Pod pretpostavkom da je Eneja junak, »njegova dominacija i prevlast u tekstu je očita, jer je opisan kao osnivač Rima. On je protagonist koji predstavlja, ne samo moralne vrline, nego je i junački okarakteriziran «, s tim da, kako utvrđuje Tamilyn H. Mulvaney, »Enejin model karakterizacije nije stvoren prema stoičkom modelu mudraca, jer on ipak izražava emocije ljutnje i bijesa. Većina antičkih junaka, poput Ahileija i Odiseja, vođena emotivnom boli i tugom zbog gubitka 
voljene osobe, postaju osvetnički nasilni. To je zato što su emotivni muškarci bili idealizirani u rimsko doba, pa je takav opisan i Eneja «. ${ }^{7}$ Prema učenjima stoičke etike, osoba ne smije biti podložna afektima, štoviše, kako tumači Seneka:

»Trenutačni afekt kojega treba odmah nadvladati, njegove posljedice su strašne za čitave narode; gnjev je u neskladu s pravom prirodom čovjeka. Ne može biti, kao što kaže Aristotel, koristan ni u ratu, jer bi onda korisno bilo pijanstvo i ludost koji, također, potiču na borbu. Gnjev nije vrlina, to je mana, veliki prijestup duše, a kao prijestup ne može popravljati druge prijestupe. Najbolje oružje čovjeka jest razum koji je u gnjevu odsutan. U gnjevu nema govora o uzvišenosti duha, samo vrlina sadrži u sebi muževnost i pravu veličinu duha« (usp. Milanovć 1995: 81).

Prema ovome, jasno je da Eneja nije okarakteriziran u duhu stoičke etike, nego je oblikovan homerskom junačkom mitološkom tehnikom, što znači da su likovi iznijansirani i razapeti emocijama straha, sažaljenja i suosjećanja, kako Aristotel u Poetici opisuje tragičke junake (usp. Aristotel 2005: 15, 1449 b1 1450 a1), samo što Eneja nije tragički, nego klasični epski junak.

\subsection{Pojam Sudbine u Eneidi}

Pojam fatuma učestalo se pojavljuje u Eneidi te svakako zahtijeva iscrpnu analizu iz više razloga. Osim što su likovi cijelom fabulom vođeni i manipulirani božjim naredbama, neizbježno je primijetiti Vergilijev opis božanskog, koji se

If we are working under the assumption that Aeneas is a hero, this should be obvious from both his predominance within the text and the fact that he is being described as the founder of the Roman line. He is our protagonist and thus we must work under the assumption that his presentation is the presentation of not only a morally virtuous, though realistic, character but also a heroic character. Most heroes, as we know them, show their sadness by taking violent revenge upon whoever harmed them or their loved one, which is distinctly not Stoic. That, however, is not the way heroes were depicted in ancient times and it is not how Aeneas is depicted here. This has been a common criticism of his character, as discussed by Bowra, however within the historical context we must not forget that Achilles brooded in his tent when his prize was taken from him during Homer's Illiad and Odysseus cried daily on Calypso's beach in Homer's Odyssey. These emotional men were idolized in Roman times, as was Aeneas. Concerning Aenea's crying, he sheds many tears throughout the story, most notably when he views the physical depiction of the fall of Troy on the temple walls in Carthage; when he tells the story of the trials he faced as Troy was destroyed; when his wife dies; and when he sees Dido in the Underworld. All of these instances are understandable as an emotionally developed human being expressing appropriate sadness fo the loss of loved ones, their homeland and their love or expressing regret for a wrong doing - as in the case of Dido. In none of these instances did Aeneas seek vengeance of any sort against those he felt responsible for his losses - though he contemplates taking vengeance against Helen during the fall of Troy (usp. Mulvaney 2012: 91-92). 
sastoji od filozofskih momenata, i doći do zaključka da se epskim izrazom izriče etičko-ontološki vid stoičkog poimanja Boga, božanske bîti i Sudbine. Calypso Nash navodi latinsku riječ za sudbinu kao fatum primjećujući da je to »najčešća riječ u Eneidi za označavanje sudbine te se pojavljuje 125 puta i ako isključimo De Fato, Vergilijevo spominjanje fatuma brojčano je veće nego u cjelokupnom Ciceronovu opusu«. Osim toga, napominje Nash, »fatum je samo jedna od riječi kojima se Vergilije poslužio u govoru o sudbini, također se često susreću riječi fortuna, Parcae, sors/sortes, a svaka dodaje svoju boju i perspektivu sudbini i njezinoj ulozi u događanjima« (usp. Nash 2017: 86).

Struktura Eneide sastoji se od dvanaest pjevanja, od kojih prvih šest slijedi Odiseju, a drugih šest Ilijadu. Poput Odiseja i Eneja silazi u podzemlje, »a njega tjera nezadrživa čežnja, ali to sada nije čežnja za povratkom domu, nego svojevrstan usud kojim je upravo on određen da osnuje rimsku državu« (usp. Solar 2003: 87). Ako bismo pojam čežnje pokušali prenijeti u filozofiju, pridobilo bi značenje odnosa spram istine ili kod stoika, Sudbine, što je prema značenju slično Platonovu erosu, koji je u Simpoziju Sokrat definirao kao vezu između stvari i ideja. ${ }^{8}$ Sudbina je isto tako svojevrsna veza između čovjeka i prirode, odnosno Boga čije svojstvo jest sama etičnost. Luciano de Crescenzo simpatično navodi da su »stoici voljeli govoriti kako se filozofija može usporediti s voćnjakom: ograda bi bila logika, drveće po kojem se penjemo fizika, a plodovi koje onda ubiremo etika« (usp. Crescenzo 2012: 291). Preko Sudbine, koja vodi preko ontološkog i logičkog, dolazimo do etičkog. Kao što naglašava Robert B. Todd u svojoj studiji:

»Phusis ili Priroda u stoičkoj je filozofiji bila vrijednosna kategorija koja je služila kao osnova etičke teorije. Prvotni element stoičkog monizma shvaćen je kao božanski i racionalan, a ono što sam nazvao njegovom imanencijom predstavljalo je također kauzalni proces koji se može odrediti kao sudbina i providnost te koji izražava teleološko shvaćanje prirode« (usp. Todd 2005: 240).

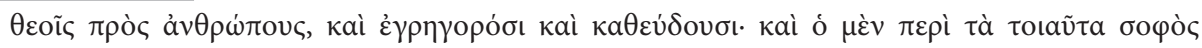

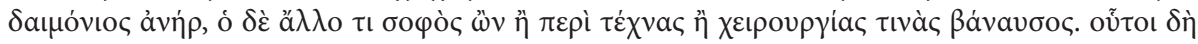

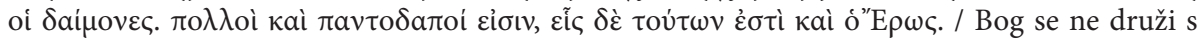
čovjekom nego se komuniciranje i razgovor bogova s ljudima i u snu i na javi obavlja isključivo posredstvom demona; i čovjek koji posjeduje mudrost u takvim stvarima božanski je, a onaj koji je mudar u drugome, ili u vještinama ili u nekim rukotvorstvima, običan je zanatlija. Ti su demoni brojni i raznih vrsta, a jedan je od njih i Eros (usp. Platon 1996: 202 e - 203 a, 104-107). 
Opisano kretanje, još u počecima naučavanja, stoici definiraju deterministički. No treba uzeti u obzir, na što nas Dorothea Frede i upozorava, da je pojam determinizma (hôrismenon) kasnog porijekla, iako je »deterministička misao u ovom ili onom obliku zaokupljala filozofe i znanstvenike od rane antike« (usp. Frede 2005: 284). Deterministička misao upućuje na vid znanstvenosti, jer otklanja mogućnost bilo čega što se ne bi moglo podvrgnuti pod općenitost kategorija. Ono što Friedrich Schelling naglašava u Filozofiji mitologije je da smo iz predavanja o grčkoj mitologiji imali

"prigodu upoznati snagu znanstvene metode. Bitno je da metoda koju ste ovdje upoznali u jednoj posebnoj primjeni ima općenito značenje, ukoliko je ona ujedno i metoda filozofije, ukoliko ona na mjesto realnog sklopa ne stavlja puki filigranski rad pojma, a općenito značenje i za druge ne manje zamršene predmete, kojima bi, uz prikladnu primjenu, mogla ovladati jednako kao što smo njezinim posredstvom ovladali mitologijom« (usp. Schelling 2000: 591).

Dakle, za Schellinga je mitološko u službi filozofske metode te je i više nego sposobno izlagati formalne sadržaje, a takvu mitološku znanstvenu metodu moguće je iščitati iz grčke mitologije. Kao bitno svojstvo epskog pjesništva mitološko se odražava »kao prethodni lik ideologije, i to kao nesvjesno svladavanje prirodne i društvene zbilje« (usp. Bubner 1997: 24), a o tome će se raspravljati u sljedećem poglavlju.

\section{Homerski faktor}

Friedrich Schelling pita se »što se razumije pod tim u Homera navodno nedostajućim mističnim« (usp. Schelling 2000: 569). Schelling je želio istražiti i uspostaviti temelj odakle Homer preuzima mistične motive i kakvo značenje to mistično dobiva u njegovim epovima, stoga kaže:

»Riječ je o osnovi, o temeljnoj građi misterija, i pitanje je da li je ta građa bila dana $s$ mitologijom, ili je bila tek kasnije odnekud donesena i prokrijumčarena u Grčku, kako to zamišljaju Voß i njegovi pristalice. A ako se pitanje odredi na ovaj način, ako nije riječ o misterijskom nauku, nego o mističnom, tad taj mistični element kojeg se u Homera ne nalazi ne može biti ništa drugo do upravo ono lažno religijsko ranijih istočnjačkih sustava. A to se dakako u Homera i ne može naći - jer to lažno jedno prikriveno je upravo politeizmom, u njemu je takoreći skriveno, njemu je postalo 
osnovom, prema tomu onim unutarnjim - dakle naravno je da u Homera mora biti nevidljivo« (usp. Schelling 2000: 569-570).

Schelling kaže da je politeizam skrio mistični moment mitologije, jer mitološki estetski izraz ponajprije u vidu ima korisnost u potvrđivanju društvenih normi zajednice, a »estetsko iskustvo egzercira na susretima sa svakodnevicom, preuzima društvenu funkciju «. Naravno da te funkcije »ne predstavljaju istinski sadržaj samog estetskog iskustva« (usp. Bubner 1997: 170-171), zato što u protivnom estetski izraz kao eksplikacija ontološkog ne bi bio moguć. Mističnost koju je Schelling uočio u homerskom epskom pjesništvu Vergilije preuzima u nešto većem zanosu, što se tiče stiliziranosti i estetiziranosti pjesničkog izraza koji zaprima filozofski moment. Poput Homera, Vergilije u svom epu izlaže filozofiju koja je u slozi s rimskom kulturom, a ideološki postavljeni filozofski stavovi imaju tendenciju ostvariti se kao svjetonazor, što u Vergilija i jest slučaj. On se ne okreće protiv realnosti i ne kritizira postojeće političko stanje, nego upravo suprotno, Vergilije razvija mitološku svijest koju je transformirao u vid skladan s praktičnim shvaćanjem života. Mističnost, kakvu je Schelling opisao, Vergiliju je poslužila samo kao oruđe kojim je zazvao bogove, ne samo u epski svijet, već putem njega i u stvarni, s etičkim opravdanjem rimskog stoicizma. Kao što kaže Bertrand Russell: „Čak i u najraspuštenijim vremenima Carstva, prosječan Rimljanin još uvijek je smatrao da je Rim nositelj čišćeg etičkog standarda, u usporedbi s dekadentnom pokvarenošću Grčke« (usp. Russell 2010: 250). Estetskim izrazom ontološke naravi Vergilije »opći s bogovima u svrhu ispravljanja ljudskog života, koje nam je poznato iz teološkog shvaćanja, sada se uknjižuje kao prilog razvijanju samosvijesti koja, zahvaljujući njoj pristupačnoj komunikaciji s onim apsolutnim, ostavlja za sobom svoju raniju ovisnost i postaje autonomnom« (usp. Bubner 1997: 164).

Joseph Farrell ističe »kako je Vergilije oduvijek uživao reputaciju pjesnika zainteresiranog za filozofska pitanja i da ga se često svrstava u pristalice određene filozofske škole« (usp. Farrell 2014: 61).

»U širem smislu, možemo govoriti o tri krucijalne ideje vezane za Vergilijeva filozofska uvjerenja, koje su ovjerene u antici i onda formalno prisvojene. Prva teza kaže da je Vergilije bio epikurejac tijekom života, a da bismo shvatili stoicizam nužno ga je neprestano uspoređivati s epikurejstvom, jer su ta dva učenja međusobno u proturječnosti. Druga teza tvrdi da je Vergilije bio orijentiran prema epikurizmu kojeg je u konačnici 
napustio u korist produhovljenije perspektive proizašle iz drugih škola i treća teza naglašava kako Vergilije nije bio strogi pristalica ove ili one škole, nego eklektički nastrojen ponajviše prema filozofskim pitanjima, nego ortodoksnim sistemima« (usp. Farrell 2014: 62).

U Eneidi Vergilije slijedi, kako kaže Farrell, »Homerov program kojim bi filozofiju postavio kao jednom od središnjih epskih tema« (usp. Farrell 2014: 79), i zato, prije nego što se krene govoriti o stoičkoj Sudbini u Eneidi, nezaobilazno je istražiti utjecaj homerskog faktora te epikurizma, kojima je Vergilije, »kao dio rimske elite, bio okružen « (usp. Nash 2017: 4). Navedena teza potvrđena je već u prvom pjevanju, u Zazivu muza oba epa, i Odiseje i Eneide, implicira se stoički shvaćena Sudbina. Primjerice, ovi početni stihovi Odiseje:

Koji se prijekoj smrti izmakoše, oni su doma /

Onda već bili svi ukloniv se ratu i moru, /

Samo je njega željnog i povratka svojeg i žene /

Držala gospođa nimfa Kalipsa u prostranoj špilji, /

Boginja uzorita, želeći da joj muž bude. /

Ali kad minuše ljeta te ona godina dođe /

Koje bogovi njemu odrediše doma na otok /

Itački vratiti se, - ni tamo med milima svojim /

On se ne presta mučit - tad bozima bude ga žao. (144) ${ }^{9}$

A Vergilije u Eneidi kaže ovako:

Pjevaj mi, Muzo, zbog čega i kojeg uvrijedivši boga, /

pravedan junak i dičan tolike je patnje i jade /

trpjeti morao gonjen od kraljice bogova ljute, /

zar su toliko bijesna domara nebeskih srca? (5)

Eneida nije samo homerska imitacija koja uključuje Ilijadu i Odiseju u svoju fabularnu strukturu, nego i »filozofske ideje pripisivane njima što nam signalizira određenu važnost egzegeze koja se tiče oba epa kao simboličke reprezentacije

Svi citati preuzeti su iz izdanja: Homer. 2003. Odiseja: izbor. U: Ilijada i Odiseja: izbor. Drugo izdanje. S grčkoga preveli Tomo Maretić i Stjepan Ivšić, s izvornikom usporedio, redigirao i prepričao neobjavljena pjevanja Damir Salopek, pogovor Milivoj Sironić, metodička obrada Dunja Merkler i Sanja Zolić Neralić, bilješke i komentari Tomo Maretić, Stjepan Ivšić i Damir Salopek, ur. Zagreb: Školska knjiga, 144-234. Stihovi 11-19. 
filozofije prirode« (usp. Farrell 2014: 80). Filozofsko čitanje Eneide ogleda se u etičko-ontološkoj problematici, a filozofija prirode bila je središnja komponenta filozofije u vrijeme Cicerona i Lukrecija, postavljajući zahtjev za znanstvenošću, baveći se disciplinama poput kozmologije, fizike, meteorologije, astrologije, kao i teološkim i religijskim spekulacijama, tj. pitanjem dobra i zla. ${ }^{10}$ Stoicizam i epikurizam nužno su utjecali na Vergilija, odnosno, etička karakterizacija likova u Eneidi utemeljena je na »dvojnim ontološkim principima racionalne prirode i razuma upućujući na eudaimoniu« (usp. Brunschwig, Sedley 2005: 20). Racionalna priroda je Božja priroda, a čovjek je pomoću razuma u stanju razumjeti prirodne zakone i tako spoznati što je moralno ispravno, stoga su glavne stoičke vrline pripisane Eneji, a to su razboritost, mudrost, umjerenost i hrabrost. Kada se razumski, bez odavanja afektima, usvoje navedene vrline, osoba postaje harmonična, u skladu s božanskim. U Homerovim epovima takvo nešto nije svjesno naglašeno, vjerojatno zato što Homer nije poznavao nekakav ortodoksni filozofski sustav kojim bi pospješio izgradnju fabularnog tijeka i odnosa među likovima. Homer iznosi teološke i filozofske stavove koji »pružaju pouku u svim elementima znanja svome narodu « (usp. Dukat 1988: 53), te na taj način poručuje filozofsku misao iskazanu kroz mitove koji su podobni za govor o kulturnoj etici. Homer je »opisao bojeve i putovanja, a to su najosnovniji arhetipovi pune ljudske egzistencije. Homerov jednostavan, konkretan, objektivan i partikularizirajući stil bez komentara autora ili likova kao da poziva na traženje poruke ili morala priče« (usp. Dukat 1988: 13). Kasnije, u klasičnom razdoblju stare Grčke, na čelu s Platonom, učinjen je bitan okret od mitologije prema filozofiji i znanosti. Damir Barbarić ističe da se:

»U staroj Grčkoj nijedno očitovanje svakodnevnog života ne da dostatno shvatiti ne sagleda li se odnos spram božanskog kao stalna i neupitna njegova podloga i pozadina, zato što za Grke egzistencija bogova nije bilo područje vjerovanja, to je nešto što je za njih bilo posve samorazumljivo«. Htjela se odrediti »bit filozofije koja je uznapredovala i stvorila svoj početak u prevladavanju mita lógosom« (usp. Barbarić 1995: 20-21).

Natural philosophy was a central component: in his brief history of philosophy in the fifth book of Tusculanae Disputationes, Cicero claims that philosophy is at heart the study of rerum natura (Cic. Tusc. 5.9), which is also the title that Lucretius gave his Epicurean poem. This comprised enquiries which we might label 'scientific', such as cosmology, physics, meteorology, and astronomy, as well as theology and religious speculation. Socrates, according to Cicero, was the first to summon 'philosophy down from the heavens and set her in the cities of men... and compel her to ask questions about life and morality and things good and evil' (Cic. Tusc. 5.11, trans. King) (usp. Nash 2017: 2). 
S druge strane, Jean-Pierre Vernant pojašnjava nam da:

»Riječ mit i dolazi od Grka, no za one Grke koji su je upotrebljavali u arhajsko doba nema isto značenje koje joj mi pridajemo danas. Mythos znači riječ, priča i on nije opreka lógosu, čije je prvo značenje isto tako riječ, govor, a tek potom umovanje i razlog. Tek će u sklopu filozofijskog izlaganja od petog stoljeća na ovamo mythos, postavljen kao opreka lógosu, zadobiti pejorativnu oznaku isprazne tvrdnje lišene vjerodostojnog svjedočanstva. Prema tome, mythos se u grčkome kontekstu ne ukazuje kao poseban oblik mišljenja već kao sveukupnost onoga što se susretima i razgovorima prenosi i širi onu bezličnu, anonimnu, neuhvatljivu moć koju Platon naziva phēmē, glasina« (usp. Vernant 2016: 9-10).

U ovom radu neće se raspravljati o tome je li i koliko je Homer utjecao na razvoj filozofskog pitanja o onome što jest, tijekom prijelaza s mitskog načina mišljenja ka znanstveno-filozofskom, ali ako "gledamo sa stajališta narodne književnosti, Homer doista jest uredio društvo i bio je otac pjesnika i izvor filozofije, sve što povijesni Homer ne bi mogao biti« (usp. Dukat 1988: 54). U Moralnim pismima Luciliju, Seneka uzdiže Homera kao filozofa govoreći:

»Naime, čas ga smatraju stoikom koji odobrava jedino vrlinu, izbjegava naslade i odbija prihvatiti i uz cijenu besmrtnosti; čas ga opet smatraju epikurejcem koji hvali samo mirno stanje u državi i život usred gozbi i veselih popijevki; čas opet peripatetikom koji uvodi tri vrste dobra, a čas akademikom koji kaže da je sve nesigurno. Jasno je da ništa od toga nije u njemu jer je sve u njemu; jer to se međusobno razlikuje. Priznajmo im da je Homer bio filozof: jer postao je svakako filozof prije nego što je poznavao ikakve pjesme; stoga učimo ono što je Homera učinilo mudracem «. ${ }^{11}$

Iz navedenog vidimo da se homerski doprinos razvoju klasičnog filozofskog mišljenja ne može i ne smije zapostaviti. Homerska etička dimenzija oblikovanja likova direktno se odnosi i na Vergilijevu Eneidu. Dok se Ilijada bazira na

11 Nisi forte tibi Homerum philosophum fuisse persuadent, cum his ipsis quibus colligunt negent; nam modo Stoicum illum faciunt, virtutem solan probantem et voluptates refugientem et ab honesto ne inmortalitis quidem pretio recedentem, modo Epicureum, laudantem statum quietae civitatis et inter convivia cantusque vitam exigentis, modo Peripateticum, tria bonorum genera inducentem, modo Academicum, omnia incerta dicentem. Apparet nihil horum esse in illo, quia omnia sunt; ista enim inter se dissident. Demus illis Homerum philosophum fuisse: nempe sapiens factus est antequam carmina ulla cognosceret; ergo illa discamus quae Homerum fecere sapientem (usp. Seneka 2016: 72). 
srdžbi glavnog junaka Ahileja te je struktura obrađena pretežno mitski, Homer u Odiseji fragmentalno iskazuje filozofičnost, ponajviše etičke naravi, tako što glavni lik uvodi u iskušenja poput besmrtnosti i vječne mladosti. Unatoč rečenom, i u Ilijadi postoje odlomci u kojima bi mogli pronaći ekvivalent onome što bi bilo blisko značenju stoičkog pojma Sudbine. Naime, Homer kaže da je trojanskom ratu bilo suđeno da se odigra, kao i Ahileju da pogine i donese slavu Grcima.

Lijući suze njemu odgòvorī Tetida zatim:

"Nä što te, dïjete moje, poròdih, nesretna mati!

Ej da kod lađa sjediš, da ne plačeš i da si sretan,

Kad ti je suđeno malo živòta, nije ga mnogo!

Ti si vijeka kratka, od sviju si bjedniji ljudi,

\section{Nà tō te svojom zlom sudbìnom ù kući rodih!}

Tu sad kazati riječ na Olimp presnježni idem

Sama gromovnom Zeusu, ej uslišit ne bi l' me htio! $(24)^{12}$

Homerov Zeus, za razliku od Vergilijeva Jupitera, »često se predomišlja, nije konzistentan, a čak i predlaže mogućnost promjene sudbine« (usp. Nash 2017: 86-87). Koliko god bismo takvo shvaćanje Homerova teksta pokušali približiti značenju stoičkog pojma Sudbine, nailazimo na problem mitologizacije koja u jednu ruku stoji nasuprot i u opoziciji filozofskom sustavu, premda je mitom itekako moguće izreći filozofsko. Ili kako je Schelling rekao:

»Mi smo doduše Zeusa i njemu pripadajuće bogove nazvali materijalnima, ali samo u suprotnosti prema idealnim bogovima, onima koji još i sad ostaju nad njima, koji se više ne misle kao postali, već samo kao čiste potencije, čiste bitnosti: oni su materijalni bogovi zato jer je realni bog postao materijom, podlogom njihova bitka. Riječ materija ne uzima se ovdje u fizičkom, nego u filozofskom smislu, u kojemu znači koliko i

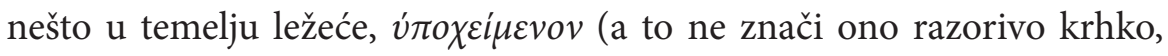
prolazno). U tom smislu bogovi nisu materijalni bogovi, nego je onako kao što Epikur za svoje bogove kaže da imaju samo nešto poput tijela, da njihova krv nije krv, nego samo nešto poput krvi. Homeros im pripisuje $\alpha \dot{\alpha} \beta \rho \circ \tau o v$, besmrtnu krv. Oni su lako živući, $\rho \varepsilon \ddot{i} \alpha \xi \dot{\omega} o v \tau \varepsilon \varsigma$, oni su samo

Svi citati preuzeti su iz izdanja: Homer. 2003. Ilijada: Prvo pjevanje. U: Ilijada. Preveo i protumačio Tomo Maretić. Pregledao i priredio Stjepan Ivšić, ur. Zagreb: Nakladni zavod Matice hrvatske, 9-33. Stihovi 413-420. 


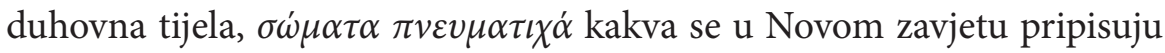
onima koji su uskrsnućem uzdignuti. Bezlični ne mogu biti, jer upravo ono po sebi neuobličeno, bezlično, ono nekoć isključivo beskonačno je u njima uobličenom a od ljudskog se lika ne da zamisliti ništa veličanstvenije« (usp. Schelling 2000: 572).

Prema Schellingovu razumijevanju odnosa mitološkog i ontološkog, čovjek je stvoren unutar božanskog, on je dio konačnoga u beskonačnom. Dakle, Bog se materijalizirao u čovjeku i tako otvorio povijest, a on jest u ljudskoj ćudorednosti. Iz ovog zaključka uviđamo da stoički panteizam očito potječe iz mitologije i epskog pjesništva arhajskog razdoblja starogrčke književnosti. Fenomenološki gledano, u mitološkim tekstovima prevladava terminološka i semantička nejasnoća, što može lako dovesti u zabludu, tako da mitološkom metodom nije moguće znanstveno ispitati pojedine filozofske probleme. Štoviše, mit je ponajprije sposoban oblikovati predrasude i praznovjerja, nego utemeljiti znanstvenu metodu, stoga, u služenju mitološkom građom kao sadržajem filozofijskog izričaja, uvijek postoji opasnost da se «zbilja odrekne svojeg ontološkog dostojanstva u prilog općeg privida kojemu svi povlađuju« (Bubner 1997: 170).

»To razlikovanje između filozofskog i izvanfilozofskog mišljenja održalo se u različitom značenju preko Platonova opisa razlike između dokse kao svakidašnjeg načina mišljenja u pećini zatočenih ljudi, te filozofskog znanja kao episteme ili čistog mišljenja pojedinačnog čovjeka koji se oslobodio pećine i koji je refleksijom dospio na slobodno svjetlo dana, te tako može gledati sunce koje prikazuje ideju dobra. Kao što je poznato, razlikovanjem između shvaćanja ljudi u pećini kao pričinskog svijeta sjena i promatranja bitka u svijetu ideja« (usp. Pažanin 2006: 684).

I zato je mit nešto što je Platon ciljano htio istisnuti iz filozofije služeći se dijalogom kao težnjom filozofa prema bitku, kojim se razdvajaju bitnosti i definira filozofija. Platon u Politeji jasno kaže da »ako ćeš primati zaslađenu Muzu u lirsko-dramskim ili epskim pjesmama, kraljevat će ti u državi naslada i bol umjesto zakona i razuma, za koji se svagda činilo, da je najbolji« (usp. Platon 2004: 607a-607b), strukturirajući stav da bi na društveno-političkom planu nekoga poput Homera i njegova pjesništva trebalo protjerati, usput spominjući da "postoji stara razmirica između filozofije i pjesništva« (usp. Platon 2004: 607b-607e). Estetičar Rüdiger Bubner tvrdi da je ta svađa 
»ontološki utemeljena, ali se ona razrješava političkim putem; jer oboje snube ljudsku dušu. Umjetnici to čine tako što stvaraju novu zbilju kojom se lako možemo zadovoljiti. Dok fikcija teži tome da prvobitnu zbilju zamijeni na zavaravajući način, filozofija se istini bitka približava pomoću dijagnoze ove zamjene« (usp. Bubner 1997: 106).

Dakle, tek od Platona pa nadalje, mit i priča strogo su odvojeni od filozofiranja te, kako je već navedeno, oni poprimaju pogrdno značenje naspram filozofiranja. No, tumačenje da mit iz filozofije nestaje nakon Platona nije točno, čak ni Platon iz svoje filozofije nije uspio prognati mitsko. Struktura filozofskih tekstova ranog stoicizma koristi se mitskim metajezikom kao sastavnim dijelom filozofiranja. Elizabeth Asmis zaključuje da u Kleantovu učenju

»nema sukoba između mitskoga i filozofskoga. Kleant tradicionalnu figuru munjevitog Zeusa preuzima u potrebe filozofije, transformirajući prvotni u sekundarni mit. Dominirajući cijelim spjevom, slika plamena s dvije oštrice munje ima utjecaj na filozofsku poruku. U sekundarnom mitu, Zeusova vatrena sila služi kao instrument kojim bi se značenje vatre moglo protumačiti i kao kazna i kao spasenje« (usp. Asmis 2007: 429).

Mit je ipak uspio zadržati svoje filozofsko značenje i poslije Platona. Uzevši u obzir da je na rani stoicizam ponajviše utjecao Aristotel, valja prepoznati kako u

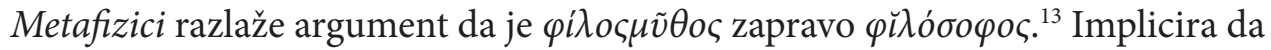
se mitsko odrazilo u lógosu, i prema tome, trojanski rat odigrao se samo zato da bi se o njemu moglo kasnije pripovijedati, odnosno, prenositi lógos, koji onda ovdje poprima značenje riječi. Schelling konstatira da:

"Nije Homer porodio mitologiju, nego je on sam porod mitologije, i to one zadnje krize. Ako je Homeros upravo onaj u kome se dovršila ona čisto mitološka svijest bogova i koji je u tom smislu svakako, kako nam to kaže tek sada razumljivi Herodot, Helenima prvi napravio teogoniju, onda se izlučivanje onog mističnog, tj. izvor, prva osnova misterija, mora misliti kao baš istovremena s Homerom. No ukoliko se taj proces izlučivanja ipak u Homerosu sasvim izveo i bio doveden do kraja, mora se tvrditi da su misterije prema svojem prvom temelju starije od onog Homera o kojem je ovdje ponajprije riječ, naime starije od gotovog, dovršenog ili tel 2001: 982 b 17-19, 8). Dakle, pjesništvo, prema Aristotelu, započinje čuđenjem kao i filozofija. 
zadnjeg Homera, kako bi možda također mogli reći« (usp. Schelling 2000: 570).

Za razliku od Platona, Aristotel ne isključuje mitsko kao filozofsku metodu, nego baš suprotno, pjesništvo izjednačava s filozofijom. Po uzoru na Homera, Vergilije preuzima mitsko kao filozofsku metodu kojom je jasno i jednostavno iznio ontološku stvarnost rimskog stoicizma, pronalazeći smisao i opravdanje filozofije u etici. Zato Vergilije »uporno karakterizira sudbinu kao literarnu, a proroke kao pjesnike, kreirajući tenziju između stoika i literarnog značaja sudbine koja mu dopušta da istraži filozofska pitanja vezana za utjecaj i čvrstu ruku sudbine« (usp. Nash 2017: 84). Iz ovih razloga, zaključuje Farrell, »čitatelji moraju biti otvoreni pri pronalasku filozofskog podteksta u svakoj točki Eneide gdje postoji homerski faktor» (usp. Farrell 2014: 80).

\section{Stoički ili epikurejski ontološki temelj}

Nash objašnjava kako su istaknutije sekte u Rimu u 1. st. pr. Kr. bili stoici i epikurejci, vjerojatno zato što su njihove filozofije bile "holistički i opsežni sistemi, a to znači da je bilo lakše jasno identificirati stoike i epikurejce nego iznijansirane i eklektičke pozicije ostalih mislioca « (usp. Nash 2017: 3). Usprkos Vergilijevu eklekticizmu, kristalno je jasno, kako navodi Mark W. Edwards, da Vergilije, "premda je moguće da je privatno bio epikurejac, svjesno preuzima stoička mišljenja kada se referira na čovjekovu vezu sa Sudbinom. Stoici su često izražavali svoju potragu za sklad s Prirodom i kozmosom kao pratnju Sudbine« (usp. Edwards 1960: 151), a to možemo prikazati usporedbom Kleantove Himne Zeusu i Eneide. Kleant u Himni Zeusu lógos definira kao božanski zakon kojemu se, ako hoćemo biti sretni i zadovoljni, moramo pokoravati.

»Bez tebe, bože, ne nastaje nijedno djelo ni na zemlji, ni u božanskom nebeskom eteru, ni u moru, izuzevši ono, što u svojem bezumlju rade opaki. $\mathrm{Pa}$ i neravno umiješ ti učiniti ravnim, davati ljepotu onome, što nije lijepo, a i ono, što nije milo, tebi je milo. Tako si naime združio u jedno sve dobro sa zlim, da od toga postaje jedinstven opći i vječni lógos. Od njega bježe i napuštaju ga svi opaki smrtnici, jadnici, koji uvijek žude za posjedom dobara, ali su slijepi i gluhi za opći božanski zakon, a da mu se pokoravaju, mogli bi živjeti razumno i sretno. No u svome bezumlju oni srljaju iz jednog zla u drugo, jedni obuzeti svadljivom revnošću oko slave, drugi tražeći dobit bez ikakva obzira, a treći opet odajući se neradu 
i lagodnoj njezi tijela. [Ali postižu zlo] pa zanoseći se sad jednim drugim revno nastoje, da se ostvari ono, što je tome protivno« (usp. Bošnjak 1957: 127). ${ }^{14}$

Usporedbom Vergilijevih stihova u Eneidi, vidimo da postoji određeno slaganje s Kleantovima, etičko-ontološki element u oba djela iznesen je mitskom metodom.

Uliks im strašni na čelu. O neki im se bozi što prije

osvete, ako ih čovjek za osvetu moliti smije.

Ti si mi pak naprotiv reci po kakvoj si ovamo zgodi

stigao još za života? Zar tvoji zalutaše brodi?

\section{Ili božanska se volja il sudba te nesretna vija}

sići u prostore tamne i tužne, gdje sunce ne sija. (155)

Edwards upozorava da riječi sequi i comitari, kojima Vergilije u Eneidi označava ono što se obično prevodi kao praćenje Sudbine, zapravo u svom korijenskom latinskom značenju uopće nemaju određenje praćenja, nego podređenosti ili subordiniranosti Sudbini. ${ }^{15}$ Dakle, stoička Sudbina je panteistički nastrojena i u smislu podređivanja materije samom sebi, depersonalizirani Bog, čija Priroda ima svoju bît u materijalizaciji same sebe kao božanskog, jest isključivo u postojanju svijeta. I tako u Eneidi bogovi izražavaju opstojnost i djelovanje kroz kozmički bijes izazvan borbama između moralno suprotstavljenih likova. Tu je Eneja koji poštuje zakone Božje prirode, i tu je Turn koji mu se suprotstavlja, a cijeli slijed događaja već je Sudbinom predodređen. Prema navedenom shvaćanju stoicizma u rimskoj kulturi, Bog je svoju Prirodu konstituirao u postojećoj primarnoj materiji na način prožimanja svih stvari pneumom te je sastavni i neodjeljivi dio kozmosa, a Sudbina, druga bît koja ima udio u Bogu, tj. lógos spermatikos, podređuje se njemu. To, naravno, ne znači da sloboda ne postoji, nego se odražava u volji pojedinca spram božanskog. Osoba dobre volje, koja prihvaća Sudbinu i pokorava joj se, kako Seneka kasnije tumači, bit će vođena, a

Branko Bošnjak navodi naslov originala: Stoicorum veterum fragmenta collegit Ioannes ab Arnim I-IV, Lipsiae et Berolini in aedibus B. g. Teubneri, 1923-1938.

15 The few passages where it appears that fortune or Fate „follows“" the hero, instead of vice-versa, can I think be satisfactorily accounted for if it is noted that sequi, together with comitari and the

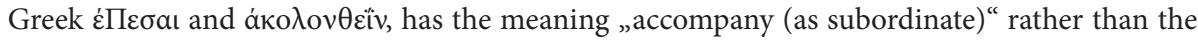
more precise „move along behind“ which the English „follow“ denotes (usp. Edwards 1960: 153). 
onaj koji odbija biti dio Boga, taj će snositi kobne posljedice te će silom Sudbine biti podveden pod Božji zakon i red. ${ }^{16}$

Nash tvrdi da je Vergilije bio upoznat s epikurejcem Filodemom, kao što je i vrlo dobro poznavao Lukrecijev spjev O prirodi stvari (usp. Nash 2017: 9), u kojem Lukrecije, tumačeći Epikura, čvrsto zastupa stav o tome da bogovi žive u savršenom stanju.

»(...) kao što i odgovara njihovoj nježnoj naravi, te uopće nisu uključeni u ljudski svijet kojeg su ipak napravili za nas, samo što im naša ljubav nije od koristi pa ni nemaju potrebu, ni zalaziti u naš svijet, ni išta poduzimati. Nije moguće ni ovo, da vjeruješ, sjedišta sveta bogova višnjih da igdje u svijetu ovome jesu: Naime, bogova narav je nježna i silno daleko. Od naših ćutila, jedva zapažljiva duševnim okom (usp. Lukrecije 2010: 151).

Poznavajući Ciceronove tekstove, Vergilije je poznavao i epikurejsku filozofiju, ali on u Eneidi ne zastupa stav o božjoj isključenosti iz ljudskog svijeta. Za razliku od Lukrecijeva iskaza o božjoj nedodirljivosti, Vergilije tvrdi upravo suprotno:

Kada to vidje Eneja, bez duše i osupnut stade, /

kosa se naježi njemu, a u grlu govor mu zapne, /

ko da je ošinut gromom nad porukom zastade božjom, /

osjeti strastvenu želju osladjelu ostavit zemlju. (92)

Vergilije bogove u Eneidi ne uzima iz epikurejske filozofije, »nego su opisani ljuti i osvetoljubivi te se upleću u ljudski život« (Nash 2017: 9), što upućuje na pomisao da se radi o stoički shvaćenom Bogu. To ne znači da u Eneidi ne postoji epikurejski element, jer stoici i epikurejci imaju zajedničkih točaka u svojim učenjima, "stoička ontologija drži da se ništa ne može istinito predicirati što se ne odnosi na tjelesno postojanje i u tom su pogledu stoici suglasni s Epikurom« (Long 2005: 261). Prema Ciceronovu razlikovanju epikurejaca i stoika u De Fato, kaže da bi Epikur radije patio i proživljavao bilo kakve nedaće, nego prihvatio stav da kauzalitetom upravlja Sudbina, dok se zapravo boji priznati Hrizipov stav da je svaka propozicija ili istinita ili lažna, jer bi onda time nužno priznao i Sudbinu. Epikur je stoga smatrao da je svaka nužnost Sudbine izbje-

16 Ducunt volentem fata, nolentem trahunt (usp. Seneka 2016: 278). 
gnuta zbog zastranjivanja atoma. ${ }^{17}$ Budući da u Eneidi nema govora o povezanosti kauzaliteta s atomima, nameće se zaključak da Vergilije ponajprije izlaže stoičku filozofiju, a bitna razlika između epikurejskog i stoičkog učenja jest u shvaćanju lógosa, dok im se etičko učenje o vrlini u velikoj mjeri podudara, iako im je ontološko određenje smisla etike u potpunosti različito. Ipak, u načelima i epikurejaca i stoika, u skladu s filozofijom prirode ponašaju se i logika i etika.

\section{Zaključak}

Poetička, a onda i filozofijska struktura Vergilijeve Eneide obilježena je homerskom, platoničkom, stoičkom i epikurejskom filozofsko-književnom tradicijom. Filozofski element zasigurno je svjesno umetnut $\mathrm{u}$ ep u okviru rimske kulture, koja je sazdana na temelju helenističko-rimske filozofije, ponajviše stoicizma kao filozofske škole koja je prevladala u svojoj popularnosti poprimajući značajke kulta i religije. Moglo bi se zaključiti da Vergilije nije u vidu imao filozofsku sastavnicu, koliko kulturno-etičku, što znači da je njegovo obilježavanje Eneide stoicizmom zapravo ideologijsko, a istu ulogu imaju i ostale filozofsko-književne tradicije koje nalazimo na intertekstualnoj razini epa. Ontološki izraz Eneide, uspostavljen stoičkom filozofijom prirode, ujedno stvara i estetsku vrijednost, a taj filozofski izraz Vergilije ozbiljuje mitskom filozofskom metodom. Mitsko prethodi i omogućuje filozofiju i religiju, pa je onda mitska filozofska metoda preteča majeutičke, kojom Platon, zastupajući teze i antiteze u dijaloškoj književnoj formi razdvaja bît od pojave. Za razliku od majeutičke, mitska filozofska metoda još uvijek nema fenomenološki vid razdvajanja bîti od pojave na znanstvenoj razini, ali ima ulogu postavljanja pitanja i davanja zadovoljavajućih odgovora o biću kao biću u kulturnom okviru njegove etičnosti i konačnosti, a to su pitanja o smislu postojanja iz kojih su kasnije izronila ključna ontološka pitanja, poput čovjekove bačenosti u svijet ili odnosu života

At this point, in the first place If I chose to agree with Epicurus and to say that not every proposition is either true or false, I would rather suffer that nasty knock than agree that all events are caused by fate; for the former opinion has something to be said, but the latter is intolerable. Accordingly Chrysippus exerts every effort to prove the view that every axiōma is either true or false. For just as Epicurus is afraid that if he admits this he will also have to admit that all events whatever are caused by fate (on the ground that if either of two alternatives is true from all eternity, that alternative is also certain, and if it is certain it is also necessary. This, he thinks, would prove both necessity and fate), similarly Chrysippus fears that if he fails to maintain that every proposition is either true or false he will not carry his point that all things happen by fate and spring from eternal causes governing future events. But Epicurus thinks that the necessity of fate is avoided by the swerve of an atom (usp. Cicero MCMXLVIII: 217). 
i smrti. Upravo su to pitanja kojima se mitovi bave od svojih početaka. Prema tome, u Vergilijevu epu mitološka je građa objašnjena i prikazana filozofski, metodom koja podrazumijeva iznošenje kulturne etike praktičnog duha putem estetskog, s preduvjetom implikacije ontološkog. Karakterizacija likova u Eneidi nije temeljena isključivo na stoičkom idealu mudraca, a ni na epikurejskom produhovljenom hedonistu, nego na tehnici oblikovanja likova grčke mitologije - materijalom kojim je Homer kreirao programski diskurs i time postao učiteljem epskog pjesništva. No postupci likova, tj. etičke posljedice, slijede stoički stav o odnosu Boga, Prirode i bića kao iskonskoj i prirodnoj konstituciji kozmosa. Dakle, fabula je podređena stoičkoj Sudbini, a likovi su oblikovani prema homerskom programu.

\section{Literatura}

Aristotel. 2001. Metafizika: Alpha knjiga. U: Metafizika. Priredio i preveo Tomislav Ladan, ur. Zagreb: Signum, Medicinska naklada.

Aristotel. 2005. O pjesničkom umijeću. Preveo i priredio Zdeslav Dukat. Jadranka Hađur, ur. Zagreb: Školska knjiga.

Asmis, Elizabeth. 2007. Myth and Philosophy in Cleanthes' Hymn to Zeus. U: Greek, Roman, and Byzantine Studies 47. Durham: Duke University, 413-429.

Barbarić, Damir. 1995. Grčka filozofija - naznake za lektiru i studij tekstova. U: Grčka filozofija. Hrestomatija filozofije. Sv. 1. Damir Barbarić, ur. Zagreb: Školska knjiga, 17-39.

Beker, Miroslav. 1997. Od Odiseja do Uliksa. Zagreb: Školska knjiga.

Bubner, Rüdiger. 1997. Estetsko iskustvo. Preveo Tihomir Engler. Priredio Damir Barbarić. Zagreb: Matica hrvatska.

Bošnjak, Branko. 1957. Filozofija od Aristotela do renesanse. U: Filozofija od Aristotela do renesanse. Filozofska hrestomatija. Sv. II. Vladimir Filipović, ur. Zagreb: Matica hrvatska.

Brunschwig, Jacques i Sedley, David. 2005. Helenistička filozofija. U: Helenistička filozofija: epikurovci, stoici, skeptici. Pavel Gregorić, Filip Grgić, Maja Hudoletnjak, ur. Zagreb: Kruzak, 1-31.

Cicero, Marcus Tullius. MCMXLVIII. De Fato. U: De Fato. Preveo na engleski H. Rackham, M.A., ur. Cambridge, Massachusetts: Harvard University Press, London: William Heinemann LTD., 192-252.

Ciceron, Marko Tulije. 2007. Lelije o prijateljstvu. U: Lelije o prijateljstvu. Preveo, opremio bilješkama i uvod napisao Zvonimir Milanović, ur. Zagreb: Cid-Nova, 89-161.

Crescenzo de, Luciano. 2012. Povijest grčke filozofije. S talijanskog prevela Jelena Butković. Zagreb: Znanje.

Dukat, Zdeslav. 1988. Homersko pitanje. Zagreb: Globus. 
Edwards, Mark W. 1960. The expression of stoic ideas in the Aeneid. Phoenix 14/3. Phoenix: Classical Association of Canada, 151-165.

Farrell, Joseph. 2014. Philosophy in Vergil. U: The Philosophizing Muse: The Influence of Greek Philosophy on Roman Poetry. Myrto Garanyi, David Konstan, ur. Newcastle: Cambridge Scholarly Publishing, 61-90.

Frede, Dorothea. 2005. Stoički determinizam. U: Helenistička filozofija: epikurovci, stoici, skeptici. Pavel Gregorić, Filip Grgić, Maja Hudoletnjak, ur. Zagreb: Kruzak, 283-306.

Gourinat, Jean-Baptiste. 2014. Stoicizam. S francuskog preveo Marko Gregorić. Zagreb: Jesenski i Turk.

Homer. 2003. Ilijada: Prvo pjevanje. U: Ilijada. Preveo i protumačio Tomo Maretić, pregledao i priredio Stjepan Ivšić, ur. Zagreb: Nakladni zavod Matice hrvatske, 9-33.

Homer. 2003. Odiseja: izbor. U: Ilijada i Odiseja: izbor. Drugo izdanje, s grčkoga preveli Tomo Maretić i Stjepan Ivšić, s izvornikom usporedio, redigirao i prepričao neobjavljena pjevanja Damir Salopek, pogovor Milivoj Sironić, metodička obrada Dunja Merkler i Sanja Zolić Neralić, bilješke i komentari Tomo Maretić, Stjepan Ivšić i Damir Salopek, ur. Zagreb: Školska knjiga, 144-234.

Jakopec, Petar. 2018. Stoička etika vrline i Rousseauova koncepcija građanske religije. Obnovljeni život: časopis za filozofiju i religijske znanosti, vol. 73, br. 1. Zagreb: Filozofsko teološki institut Družbe Isusove, 95-105.

Long, Anthony A. 2005. Duša i tijelo u stoicizmu. U: Helenistička filozofija: epikurovci, stoici, skeptici. Pavel Gregorić, Filip Grgić, Maja Hudoletnjak, ur. Zagreb: Kruzak, 259-281.

Lukrecije Kar, Tit. 2010. Peto pjevanje: Kozmologija i povijest kulture. U: O prirodi. S latinskoga prepjevao Marko Tepeš, ur. Zagreb: Kruzak, 147-189.

Maron, Publije Vegilije. 2005. Eneida. U: Eneida. S latinskog preveo Bratoljub Klaić, ur. Zagreb: Globus media, Biblioteka Jutarnjeg lista.

Mikecin, Igor. 2003. Etičko opravdanje Rimskog Imperija. Sociologija i prostor: časopis za istraživanje prostornoga i sociokulturnog razvoja 41, 1/2 (159/160). Zagreb: Institut za društvena istraživanja u Zagrebu, 131-146.

Milanović, Zvonimir. 1995. Seneka: Ideal i kult stoicizma. Preveo i napisao Zvonimir Milanović, ur. Zagreb: Cid.

Milanović, Zvonimir. 2007. Marko Tulije Ciceron. U: Marko Tulije Ciceron: život i djelo. Zvonimir Milanović, prijevod i obrada, ur. Zagreb: Cid-Nova, 5-89.

Mulvaney, Tamilyn H. 2012. The Source of Morality for Virgil's Aeneid. Electronic Theses and Dissertations. 4831. https://scholar.uwindsor.ca/etd/4831

Nash, Calypso. 2017. Philosophical Readings in Virgil's Aeneid. Oxford: Balliol College, DPhil in Classical Languages and Literature.

Pažanin, Ante. 2006. Pokušaj utemeljenja ontološke etike. Filozofska istraživanja 26/3. Zagreb: Hrvatsko filozofsko društvo, 677-699.

Pearson, A. C. 1891. Introduction. U: The fragments of Zeno and Cleanthes: with introduction and explanatory notes, ur. London: printed by C. J. Clay and Sons at Cambridge University Press, 1-53. 
Platon. 1996. Simpozij ili O Ljubavi. U: Eros i Filia. Preveo sa starogrčkog Zdeslav Dukat, ur. Zagreb: Demetra.

Platon, 2004. Deseta knjiga. U: Država. Preveo Martin Kuzmić, ur. Zagreb: Naklada Jurčić.

Russell, Bertrand. 2010. Povijest zapadne filozofije. Prevela Danira Palenta. Zagreb: Ibis grafika.

Schelling, Friedrich Wilhelm Joseph. 2000. Dvadeset osmo predavanje. U: Filozofija mitologije. Svezak drugi. Druga knjiga: Mitologija, predavanja 14-29. Preveo Damir Barbarić, ur. Zagreb: Demetra.

Seneka, Lucije Anej. 2016. Ad Lucilium Epistulae Morales. U: Ad Lucilium Epistulae Morales. Svezak drugi. Pismo 82-124. Preveo Tvrtko Milunović, ur. Zagreb: Demetra.

Solar, Milivoj. 2003. Povijest svjetske književnost: kratki pregled. Zagreb: Golden marketing.

Stob, Ralph. 1935. Stoicism and Christianity. Classical Journal 30/4. The Classical Association of the Middle West and South, Inc., 217-224.

Todd, Robert B. 2005. Monizam i imanencija: temelji stoičke fizike. U: Helenistička filozofija: epikurovci, stoici, skeptici. Pavel Gregorić, Filip Grgić, Maja Hudoletnjak, ur. Zagreb: Kruzak, 239-258.

Vernant, Jean-Pierre. 2016. Geneza grčke misli. S francuskog preveo Daniel Bučan. Zagreb: Demetra.

Vratović, Vladimir. 2008. Rimska književnost, Zagreb: Biakova. 


\title{
THE MYTHICAL AS A PHILOSOPHICAL METHOD IN VERGIL'S AENEID
}

\author{
Abstract \\ Filip KRAJINA \\ Josip Juraj Strossmayer University of Osijek \\ Faculty of Humanities and Social Sciences \\ Lorenza Jägera 9 \\ HR - 31000 Osijek, Croatia \\ fkrajina74@gmail.com \\ Zdravko PERIĆ \\ Josip Juraj Strossmayer University of Osijek \\ Faculty of Humanities and Social Sciences \\ Lorenza Jägera 9 \\ HR - 31000 Osijek, Croatia \\ zperic@ffos.hr
}

In this paper we discuss potential interpretations of Vergil's Aeneid from a philosophical perspective, which includes the Homeric, Stoical and Epicurean element, because the comparison of Homer's epics and Vergil's Aeneid in the figuration of a literary text and philosophicity shows congruence. Platonic influence on Vergil, through Cicero and his eclectic philosophical approach, lies in the teaching of virtue. It is therefore essential to separate the ideas of the aforementioned philosophical systems in Vergil's epic and explain his mode of exposition by the mythical philosophical method. The plot and the causal and consequential links in the epic are controlled by God's Fate which is Stoically understood, meaning that the whole narrative structure is subordinated to the founding of Rome as an empire which God had intended to rule justly and well. Along with the ethical component, there is a relation with the ontological, because the philosophy of the Epicureans and the Stoics is characterized by the division of philosophy into ethics, logic and philosophy of nature. Aeneas' model of characterization was not created according to the Stoic wise man ideal nor to the Epicurean, but the main role is that of a Homeric hero, as Aeneas still expresses emotions of anger and fury, as do most of the ancient heroes like Achilles and Odysseus, who, guided by emotional pain and grief owing to losing loved ones, became vengefully violent. The reason of such narrative motif is the idealization of emotional men in the Hellenistic period, as well as in the Roman 
period. Therefore, what was crucial in shaping the main character and his relationship towards the divine is the Roman culture and its ethical-ontological demands, which are manifested in religious form. The originator of the mythical philosophical method structured in epic poetry is Homer, whose latter influence establishes the principle for the formation of the epic. It is about the method of bringing out ideologized ethics, which is why it is cultural, and is formed by aestheticizing the mythological.

Keywords: Cicero, Aeneid, ethics, myth, ontology, Vergil 